\title{
Demographic and Clinical Factor of IUGR Baby in West Java General Hospital
}

\author{
Pipih Afiyatin ${ }^{*}$, Firman Fuad Wirakusumah'2, Hadi Susiarno 3 , Sofie Rifayani Krisnadi², \\ Jusuf Sulaeman Effendi², Supriyadi Gandamihardja ${ }^{4}$ \\ ${ }^{1}$ Obstetrics and Gynaecology Department, Sumedang General Hospital, Sumedang, Indonesia \\ ${ }^{2}$ Obstetrics and Gynaecology Department, Fetal and Maternal Medicine Division, Hasan Sadikin General \\ Hospital, Bandung, Indonesia \\ ${ }^{3}$ Obstetrics and Gynaecology Department, Social Division, Hasan Sadikin General Hospital, Bandung, Indonesia \\ ${ }^{4}$ Obstetrics and Gynaecology Department, Gynaecology and Oncology Division, Hasan Sadikin General Hospital, \\ Bandung, Indonesia \\ Email: *pipih.obgyn@gmail.com
}

Received 25 May 2015; accepted 10 June 2015; published 18 June 2015

Copyright (C) 2015 by authors and OALib.

This work is licensed under the Creative Commons Attribution International License (CC BY).

http://creativecommons.org/licenses/by/4.0/

(c) $\underset{\mathrm{EY}}{\mathrm{i}}$ Open Access

\section{Abstract}

Objective: To investigate the characteristic of the term intrauterine growth restriction (term IUGR) and analyze the correlation of demographic and clinical factor's to term intrauterine growth restriction in West Java general hospitals. Method: This study was done retrospectively using cohort method taken on July 2014. The data were taken from Indonesian Maternal and Perinatal Registration. The data were collected since April $1^{\text {st }} 2014$ to September $30^{\text {th }} 2014$. Term patients $(\mathrm{n}=$ 7.320) were divided into 2 categories: normal fetal growth and intrauterine growth restriction. The data were analysed using chi square and multiple logistic regression. Result: There are 10.4\% patients with intrauterine growth restriction. Incidence of term IUGR is commonly found in mothers less than 20 years old, low educational status (primary school), multiparity, and pregnancy interval $>2$ years, history of stillbirth, diabetes, hypertension, hypertension in pregnancy, and antepartum haemorrhage. There are significant correlations between the maternal and perinatal risk factors to the incidence of intrauterine growth restriction $(p<0.05)$. Low educational status increases the risk of having term IUGR by 1.5 times, hypertension in pregnancy by 1.3 times, and antepartum haemorrhage more than 3 times $(p<0.05)$. Conclusion: There are correlations among educational status, hypertension in pregnancy and antepartum haemorrhage with the incidence of intrauterine growth restriction. Healthcare providers should improve their knowledge about IUGR risk factors.

\section{Keywords}

Clinical Factor, Demographic Factor, Intrauterine Growth Restrictiom

${ }^{*}$ Corresponding author.

How to cite this paper: Afiyatin, P., Wirakusumah, F.F., Susiarno, H., Krisnadi, S.R., Effendi, J.S. and Gandamihardja, S. (2015) Demographic and Clinical Factor of IUGR Baby in West Java General Hospital. Open Access Library Journal, 2: e1609.

http://dx.doi.org/10.4236/oalib.1101609 


\section{Introduction}

Intrauterine Growth Restriction (IUGR) is the term used to designate a fetus that has not reached its growth potential because of genetic or environmental factors. IUGR results in the birth of an infant who is small for gestational age (SGA). It is a disorder that can be found during pregnancy which causes significant mortality and perinatal morbidity rate. The incidence rate of IUGR is $10 \%$. Perinatal mortality rate in IUGR increases 6 10 times compared with normal baby and it is the $2^{\text {nd }}$ leading factor that causes perinatal mortality rate [1]. There is an increased incidence of asphyxia, meconeal aspiration, hypoglycaemia, hypothermy, and polycytemia that cause neurological defect either in term or preterm baby [2]-[4].

Incidence of IUGR ranged about 3\% - 7\% with average of 5.13\% depends on the population, geography and terms used in each region. According to Kay et al. [5], one third of low birth weight babies are having IUGR. Almost 4\% - 8\% of IUGR babies come from developing countries with 6\% - 30\% diagnosed with IUGR. Incidence of IUGR in Indonesia is not yet known, but according to Basic Health Research (RISKESDAS), it is said that the incidence of low birth weight baby is $10.2 \%$ from all birth [6]. There are some risk factors contributing to the incidence of IUGR which are low socio-economic status, history of IUGR, bad obstetric history, underweight before pregnancy, and obstetric complication during pregnancy [7]. Some pathogenesis responsible for incidence of IUGR are fetal factors (infection, malformation, etc.), maternal factors (cardiovascular disease, drug, tobacco, etc.), placental factors (placenta previa, abruption placenta, etc.), and uterine factors (chronic hypertension, diabetes mellitus) [4] [8].

Management of IUGR during pregnancy and labour depends on the gestational age and maternal or fetal condition. Inpreliminary to four other fetomaternal centres in Indonesia on 2004-2005, there are 571 cases of IUGR from 14.702 delivery with average of $4.40 \%$ with minimum of $2.08 \%$ in Soetomo General Hospital Surabaya and the highest number in Dr. Sardjito General Hospital Yogyakarta with 6.44\%. There are 66.2\% of IUGR babies who are having vaginal delivery and others are having c-section [9].

According to RISKESDAS, the incidence rate of low birth weigh in West Java is $11.0 \%$, higher than national rates with $10.2 \%$ [10]. These data didn't show the actual figure of IUGR number in Indonesia. Therefore, further study needs to be conducted to assess actual number of IUGR rate in West Java, and do the initial screening to eliminate IUGR risk factors.

West Java with an area of $35.377 .76 \mathrm{~km}^{2}$, and population of 46,497,175 people [6], is a large province with high urban and rural population that cause difficulties in data collection. Because of the ineffective data collection, it will affect the effectiveness for problem solving. Unreported or uncomplete data will cause difficulties in understanding and problem solving.

West Java with 46 million peoples (20\%) from total population in Indonesia [11], makes it could represents the condition of Health Status in Indonesia. Data collection taken from Indonesia Maternal Perinatal Registration (MPRI) expected to represent the health status in Indonesia so that this study was aimed to solve the IUGR problem in Indonesia.

There are 54 public hospitals in West Java [9] that accept referral patients from primary health care. Dr. Hasan Sadikin General Hospital as the primary referral hospital in West Java that functions as teaching hospital has associate hospitals that spread in several districts. From April to September 2012, each of these hospitals did a data collection method called Maternal and Child Monitoring (MCM). This MCM is recapitulated in Indonesian Maternal and Perinatal Registration. One of the goals from MPRI is to provide evidence based on neonatal mortality rate in West Java, so these data can be used to lower neonatal mortality rate [11].

Maternal risk factor for IUGR was divided based on demography, clinical and outcome. This sample was analysed to define the prevalence of IUGR based on risk factors. Demographic factors analysed in this study are age, educational status, and pregnancy interval. Clinical factors are history of stillbirth, underlying disease and pregnancy complications [4].

\section{Methods}

This study design is analytic retrospective cohort, hospital based population. Subjects taken from all patients di- 
agnosed with IUGR on 11 West Java General Hospital. The inclusion criteria are:

1) MPRI data from 11 general hospitals in West Java from $1^{\text {st }}$ April 2012-30 ${ }^{\text {th }}$ September 2012.

2) Singleton pregnancy.

3) Term gestational age (37 - 42 weeks).

The data processed as univariable, bivariable and multivariable analyses. Statistical analysis for categorical data were performed with Chi-square test, and then the odds ratio was determined, with the confidence index of $95 \%$ by value $\mathrm{p} \leq 0.05$ Multivariable analysis was used to determine the correlation between risk factors that plays role in IUGR and the dominant risk factors that cause IUGR. The data analysed again using multiple logistic regression. The data then analysed using SPSS $21^{\text {st }}$ version.

\section{Result}

From 11 district hospitals, data was grouped then processed through editing, computerized data entry, and final data selection for further analysis.

There are more than 13,000 collected from MPRI, but only 10,394 can be included for further analysis. There are 7320 term deliveries with 732 cases (10.4\%) of term IUGR. There are $0.92 \%$ cases were not included during analysis because incomplete data (Table 1 ).

Table 1 shows that incidence of term IUGR in West Java Hospital during April-September 2012 is 10.41\%, the highest incidence of term IUGR comes from Ujung Berung General Hospital with 14.4\%. There are 12\% (173 cases) term IUGR pasien with history of hypertension in pregnancy and 88\% (1272 cases) with non term IUGR baby. $\mathrm{p}$ value is $0.03(\mathrm{p}<0.05)$, it means that this result is significant statistically from term IUGR patient with hypertension in pregnancy.

There $23.4 \%$ (33 cases) term IUGR patient having history of antepartum haemorrhage. Chi-square value is $\mathrm{p}$ $=0.000(\mathrm{p}<0.05)$, it means that the result is significant from term IUGR baby with history of antepartum haemorrhage in pregnancy.

Table 2 shows that educational status, hypertension in pregnancy, and antepartum haemorrhage have significant correlation to the incidence of term IUGR.

Most of the term IUGR patients found in mother with primary school as their educational status with $11.8 \%$ (244 cases). Chi-square p value 0.013 ( $\mathrm{p}<0.05$ ), it means there are significant correlation between educational status and term IUGR (Table 3).

Table 1. Distribution of term IUGR patients during April-September 2012.

\begin{tabular}{|c|c|c|c|c|c|}
\hline \multirow{2}{*}{ RSU } & \multicolumn{2}{|c|}{ Term IUGR } & \multicolumn{2}{|c|}{ Non term IUGR } & \multirow{2}{*}{ Total } \\
\hline & $\mathbf{N}$ & $\%$ & $\mathbf{N}$ & $\%$ & \\
\hline 1. RS Hasan Sadikin & 132 & 10.4 & 1137 & 89.6 & 1269 \\
\hline 2. RS Astanaanyar & 67 & 1.0 & 893 & 93.0 & 960 \\
\hline 3. RS Cianjur & 108 & 12.3 & 770 & 87.7 & 878 \\
\hline 4. RS Cibabat & 54 & 1.3 & 525 & 90.7 & 579 \\
\hline 5. RS Garut & 91 & 11.4 & 705 & 88.6 & 796 \\
\hline 6. RS Majalaya & 35 & 1.7 & 324 & 90.3 & 359 \\
\hline 7. RS Soreang & 86 & 12.5 & 604 & 87.5 & 690 \\
\hline 8. RS Subang & 33 & 1.1 & 372 & 91.9 & 405 \\
\hline 9. RS Sumedang & 63 & 1.8 & 655 & 91.2 & 718 \\
\hline 10. RS Syamsudin & 12 & 12.4 & 85 & 87.6 & 97 \\
\hline 11. RS Ujungberung & 81 & 14.4 & 488 & 85.8 & 569 \\
\hline Total & 762 & 10.41 & 6558 & 89.59 & 7320 \\
\hline
\end{tabular}


Table 2. Difference between demographic and clinical factor in term IUGR and non term IUGR baby in West Java general hospital during April-September 2012.

\begin{tabular}{|c|c|c|c|c|c|}
\hline \multirow{2}{*}{ Variable } & \multicolumn{2}{|c|}{ Term IUGR } & \multicolumn{2}{|c|}{ Non term IUGR } & \multirow{2}{*}{$\begin{array}{c}X^{2} \\
\text { p value }\end{array}$} \\
\hline & $\mathbf{N}$ & $\%$ & $\mathbf{N}$ & $\%$ & \\
\hline Age (year) & & & & & 0.388 \\
\hline$<20$ & 88 & 11.5 & 680 & 88.5 & \\
\hline $20-35$ & 534 & 10.1 & 4735 & 89.9 & \\
\hline$>35$ & 139 & 11.1 & 1118 & 88.9 & \\
\hline Educational status & & & & & 0.013 \\
\hline Primary school & 244 & 11.8 & 1823 & 88.2 & \\
\hline Junior high school & 252 & 10.2 & 2221 & 89.8 & \\
\hline Senior high school & 201 & 9.4 & 1940 & 90.6 & \\
\hline College/university & 40 & 7.7 & 477 & 92.3 & \\
\hline Parity & & & & & 0.772 \\
\hline Primipara & 485 & 10.4 & 4186 & 89.6 & \\
\hline Multipara & 174 & 11.0 & 1407 & 89.0 & \\
\hline Grande multipara & 40 & 10.3 & 350 & 89.7 & \\
\hline Pregnancy interval & & & & & 0.095 \\
\hline$<2$ years & 400 & 9.8 & 3663 & 90.2 & \\
\hline$>2$ years & 342 & 11.1 & 2750 & 88.9 & \\
\hline History of still birth & & & & & 0.713 \\
\hline Yes & 8 & 11.8 & 60 & 88.2 & \\
\hline No & 754 & 10.4 & 6498 & 89.6 & \\
\hline \multicolumn{6}{|l|}{ Underlying disease } \\
\hline Diabetes & & & & & 0.835 \\
\hline Yes & 5 & 11.4 & 39 & 88.6 & \\
\hline No & 757 & 10.4 & 6519 & 89.6 & \\
\hline Hypertension & & & & & 0.066 \\
\hline Yes & 72 & 12.7 & 496 & 87.3 & \\
\hline No & 690 & 10.2 & 6062 & 89.8 & \\
\hline Renal disease & & & & & 0.193 \\
\hline Yes & 1 & 33.3 & 2 & 66.7 & \\
\hline No & 761 & 10.4 & 6558 & 89.6 & \\
\hline \multicolumn{6}{|l|}{ Pregnancy complication } \\
\hline Pregnancy hypertension & & & & & 0.03 \\
\hline Yes & 173 & 12.0 & 1272 & 88.0 & \\
\hline No & 589 & 10.0 & 5286 & 89.6 & \\
\hline Antepartum haemorrhage & & & & & 0.000 \\
\hline Yes & 33 & 23.4 & 108 & 76.6 & \\
\hline No & 723 & 10.4 & 6239 & 89.6 & \\
\hline
\end{tabular}

Notes: "Analysed using chi-square; CI: confidence interval. 
Table 3. Correlation between demographic and clinical factor to incidence of term IUGR in West Java general hospital from April-September 2012.

\begin{tabular}{|c|c|c|c|c|c|c|}
\hline \multirow{2}{*}{ Variable } & \multicolumn{2}{|c|}{ Term IUGR } & \multicolumn{2}{|c|}{ Non term IUGR } & \multirow{2}{*}{$p$ value } & \multirow{2}{*}{$\begin{array}{c}\text { Crude OR } \\
\text { (CI 95\%) }\end{array}$} \\
\hline & $\mathbf{n}$ & $\%$ & $\mathbf{n}$ & $\%$ & & \\
\hline Age & & & & & 0.388 & \\
\hline$<20$ & 88 & 11.5 & 680 & 88.5 & & $1.15(0.90-1.46)$ \\
\hline $20-35$ & 534 & 10.1 & 4735 & 89.9 & & 1.0 \\
\hline$>35$ & 139 & 11.1 & 1118 & 88.9 & & $1.10(0.91-1.32)$ \\
\hline Educational status & & & & & 0.013 & \\
\hline Primary school & 244 & 11.8 & 1823 & 88.2 & & $1.60(1.13-2.26)$ \\
\hline Junior high school & 252 & 10.2 & 2221 & 89.8 & & $1.35(0.96-1.92)$ \\
\hline Senior high school & 201 & 9.4 & 1940 & 90.6 & & $1.24(0.87-1.76)$ \\
\hline College/university & 40 & 7.7 & 477 & 92.3 & & 1.0 \\
\hline Parity & & & & & 0.772 & \\
\hline Primipara & 485 & 10.4 & 4186 & 89.6 & & 1.0 \\
\hline Multipara & 174 & 11.0 & 1407 & 89.0 & & $1.07(0.89-1.28)$ \\
\hline Grande multipara & 40 & 10.3 & 350 & 89.7 & & $0.99(0.70-1.34)$ \\
\hline Pregnancy interval & & & & & 0.095 & \\
\hline$<2$ years & 400 & 9.8 & 3663 & 90.2 & & $0.88(0.75-1.02)$ \\
\hline$>2$ years & 342 & 11.1 & 2750 & 88.9 & & $1.15(0.55-2.41)$ \\
\hline Stillbirth history & & & & & 0.713 & \\
\hline Yes & 8 & 11.8 & 60 & 88.2 & & $1.15(0.55-2.41)$ \\
\hline No & 754 & 10.4 & 6498 & 89.6 & & \\
\hline \multicolumn{7}{|l|}{ Underlying disease } \\
\hline Diabetes & & & & & 0.835 & \\
\hline Yes & 5 & 11.4 & 39 & 88.6 & & $1.10(0.43-2.81)$ \\
\hline No & 757 & 10.4 & 6519 & 89.6 & & \\
\hline Hypertension & & & & & 0.066 & \\
\hline Yes & 72 & 12.7 & 496 & 87.3 & & $1.23(0.98-1.65)$ \\
\hline No & 690 & 10.2 & 6062 & 89.8 & & \\
\hline Renal disease & & & & & 0.193 & \\
\hline Yes & 1 & 33.3 & 2 & 66.7 & & $4.3(0.39-47.56)$ \\
\hline No & 761 & 10.4 & 6558 & 89.6 & & \\
\hline \multicolumn{7}{|c|}{ Pregnancy complication } \\
\hline Hypertension in pre & & & & & 0.03 & \\
\hline Yes & 173 & 12.0 & 1272 & 88.0 & & $1.22(1.02-1.46)$ \\
\hline No & 589 & 10.0 & 5286 & 89.6 & & \\
\hline Antepartum haemor & & & & & 0.000 & \\
\hline Yes & 33 & 23.4 & 108 & 76.6 & & $2.64(1.77-3.92)$ \\
\hline No & 723 & 10.4 & 6239 & 89.6 & & \\
\hline
\end{tabular}

Description: *Analysed using chi-square; OR: odd ratio; CI: confidence interval. 
Bases on history of pregnancy complication, there are 12\% (173 cases) term IUGR patients with pregnancy hypertension with $\mathrm{p}$ value of $0.03(\mathrm{p}<0.05)$. It means that there are significant correlation between pregnancy hypertension and term IUGR.

There are $23.4 \%$ (33 cases) term IUGR patients with antepartum haemorrhage as their pregnancy complication with chi-square $\mathrm{p}$ value of $0.000(\mathrm{p}<0.05)$. It means there are significant correlations between antepartum haemorrhage and term IUGR.

Logistic regression test shows that low educational status such as primary school increase the incidence for term IUGR by 1.5 times, junior high school by 1.3 times and senior high school by 1.2 times $(\mathrm{p}<0.05)$. Hypertension in pregnancy also increase the incidence of term IUGR by 1.3 times and antepartum haemorrhage by more than 3 times (Table 4).

\section{Discussion}

Educational status, poverty and health care access are important aspects to increase national health status. Well educated woman give them more knowledge about how to take care of themselves during pregnancy. Low educated woman tend to ignore their health status even when they are pregnant and they are a bad decision maker. Some study concluded that low educated woman (primary school) have higher risk factor for having IUGR during pregnancy [12].

Table 4. Multiple logistic regression from risk factor of term IUGR.

\begin{tabular}{|c|c|c|c|c|}
\hline Variable & Koef. B & SE (B) & Nilai $\mathbf{p}$ & Adjusted OR (IK 95\%) \\
\hline \multicolumn{5}{|l|}{ I. Starting model } \\
\hline \multicolumn{5}{|l|}{ Parity } \\
\hline - Primipara & - & - & - & 1.00 \\
\hline - Multipara & 0.065 & 0.094 & 0.485 & $1.067(0.888-1.282)$ \\
\hline - $\quad$ Grande multipara & -0.014 & 0.174 & 0.937 & $0.986(0.702-1.386)$ \\
\hline \multicolumn{5}{|l|}{ Educational status } \\
\hline$-\quad S D$ & 0.389 & 0.182 & 0.032 & $1.476(1.034-2.108)$ \\
\hline - SMP & 0.252 & 0.181 & 0.165 & $1.286(0.902-1.835)$ \\
\hline - SMA & 0.196 & 0.183 & 0.285 & $1.217(0.849-1.744)$ \\
\hline - $\quad$ Akademi/PT & - & - & - & 1.00 \\
\hline Pregnancy interval & 0.115 & 0.081 & 0.154 & $1.122(0.958-1.314)$ \\
\hline Hypertension & -0.010 & 0.157 & 0.947 & $0.990(0.728-1.345)$ \\
\hline Renal disorder & 1.315 & 1.237 & 0.288 & $3.727(0.330$ - 42.11) \\
\hline Pregnancy hypertension & 0.266 & 0.111 & 0.017 & $1.304(1.049-1.621)$ \\
\hline Antepartum haemorrhage & 1.138 & 0.222 & 0.000 & $3.121(2.020-4.823)$ \\
\hline \multicolumn{5}{|l|}{ II. Final model } \\
\hline \multicolumn{5}{|l|}{ Educational status } \\
\hline$-\quad \mathrm{SD}$ & 0.401 & 0.182 & 0.027 & $1.494(1.047-2.133)$ \\
\hline - SMP & 0.253 & 0.181 & 0.163 & $1.288(0.903-1.837)$ \\
\hline - SMA & 0.195 & 0.183 & 0.287 & $1.216(0.849-1.742)$ \\
\hline - $\quad$ Akademi/PT & - & - & - & 1.00 \\
\hline Pregnancy hypertension & 0.277 & 0.099 & 0.005 & $1.319(1.088-1.601)$ \\
\hline Antepartum haemorrhage & 1.150 & 0.222 & $<0.001$ & 3.159 (2.045 - 4.878) \\
\hline
\end{tabular}

Description: Data were count and tested using multiple regression test (Wald test), model accuracy 89.6. OR: odd ratio. 
Some studies concluded that high educated woman showed healthy behaviour and tend to take care of themselves better [12].

Theoritically, antepartum haemorrhage is a risk factor to IUGR because of oxygen insufficiency to the fetal that cause prolong state of hypoxia. There are 15\% of IUGR cases having antepartum haemorrhage as their pregnancy complication. In this study, we found that there are significant relationship between antepartum haemorrhage with IUGR [13]. Anemia caused by antepartum haemorrhage also a risk factor of IUGR. Anemia in pregnancy have an important pathogenesis in IUGR by disrupting uteroplacental circulation. Decreasing uteroplacental sirculation will cause less or insufficient oxygen transport to the fetus. Physiological anemia during pregnancy that cause hemodilution have no effect to IUGR [14].

In this study, hypertension in pregnancy show significant relationship to IUGR. There are shallow cytothrophoblast invasion to the uterus and abnormal differentiation cytothrophoblast in the placenta of preeclampsia mother. Failed or cytothrophoblast error remodelling will cause artery spasm that cause vascular constriction that cause decreasing insufficient blood perfusion that leads to hypoxia to the baby and causing IUGR [14] [15].

\section{Conclusions}

Incidence of term IUGR in West Java is $10.4 \%$. Incidence of term IUGR has a higher rate in: 1) low educated mother, 2) hypertension in pregnancy, 3) antepartum haemorrhage. There are correlations between demographic factor (low educational status) and clinical factor (pregnancy hypertension, antepartum haemorrhage) with IUGR in term delivery at West Java general hospital during April-September 2012. Low educational status (primary school) increases the risk of IUGR by 1.5 times, pregnancy hypertension by 1.3 times, and antepartum haemorrhage by more than 3 times.

\section{References}

[1] Silver, L.E., Decamps, P.J., Korst, L.M., Platt, L.D. and Castro, L. (2003) Intrauterine Growth Restriction Is Accompanied by Decreased Renal Volume in the Human Fetus. American Journal of Obstetrics Gynecology, 188, 1320-1325. http://dx.doi.org/10.1067/mob.2003.270

[2] Dutta, D.C. (2004) Text Book of Obstetrics including Perinatology and Contraception. 5th Edition, New Central Book Agency, Philadelphia.

[3] Alkalay, A. (2013) Intra Uterine Growth Restriction 2013. http://www.google.com

[4] Cunningham, F.G., Leveno, K.J., Rouse, D.J., Bloom, S.L., Hauth, J.C. and Spong, C.Y. (2012) Williams Obstetrics. 23rd Edition, McGraw Hill, New York, 1111-1139.

[5] Kay, H. (2014) Fetal Intrauterine Growth Retardation (TERM IUGR) 2001. https://iame.com/online/TERM IUGR/Term IUGR.html

[6] SIAK Jabar (2012) Pemerintah Provinsi Jawa Barat. http://jabarprov.go.id/index.php/pages/id/75

[7] Lin, C.C. and Evans, M.I. (1984) Pathophysiology and Clinical Management. McGraw-Hill Book Co., New York.

[8] Romero, R. (2013) Term IUGR. Dalam. In: Creasy, R.K. and Resnik, R., Eds., Creasy and Resnik's Maternal-Fetal Medicine: Principles and Practice, 7th Edition, Elsevier, Philadelphia, 558-572.

[9] Kemenkes, R.I. (2013) Data Rumah Sakit Online. http://sirs.buk.depkes.go.id/rsonline/report/report_by_catrs.php

[10] Harper, T. and Lam, G. (2002) Fetal Growth Restriction.

[11] MPRI (2013) Maternal Perinatal Registration Indonesia. https://mpri-mosos.com/

[12] Sustini, F. and Lestari, P. (2011) Dasar-dasar demografi. Bunga rampai obstetri dan ginekologi sosial. Bina Pustaka Sarwono Prawirohardjo, Jakarta, 96-98.

[13] Howarth, C., Gazis, A. and James, D. (2007) Associations of Type 1 Diabetes Mellitus, Maternal Vascular Disease and Complications of Pregnancy. Diabetic Medicine, 24, 1229-1234. http://dx.doi.org/10.1111/j.1464-5491.2007.02254.x

[14] RCOG (2013) The Investigation and Management of the Small-for-Gestational-Age Fetus. http://www.rcog.org.uk/womens-health/investigation-and-management-small-gestational-age-fetus-green-top-31

[15] Allen, V.M., Joseph, K.S., Murphy, K.E., Magee, L.A. and Ohlsson, A. (2004) The Effect of Hypertensive Disorders in Pregnancy on Small for Gestational Age and Stillbirth: A Population Based Study. MBC, 4, 17-25. 